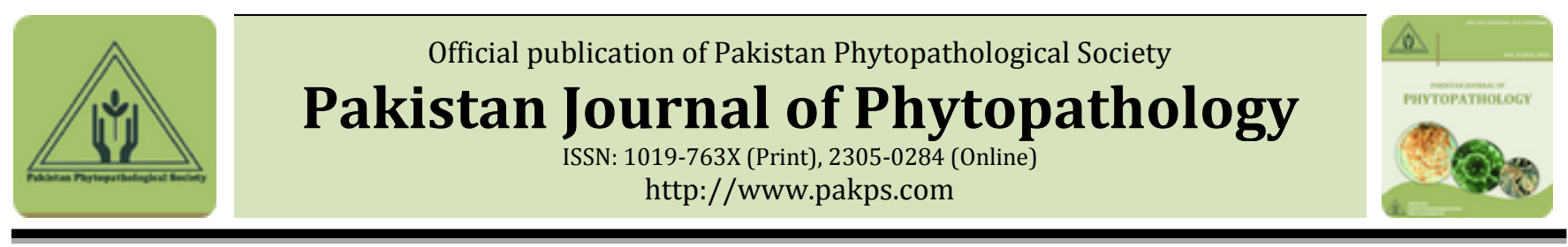

\title{
ASSESSMENT OF SOIL AND SEED BORNE FOLIAR BLIGHT DISEASES OF WHEAT OF POTHOHAR REGION
}

\author{
Sadia Sami*, Summiya Sami, Syeda Q. Batool, Shazia Iftikhar \\ a Department of Environmental Sciences, Fatima Jinnah Women University, The Mall Rawalpindi, Pakistan.
}

\section{A B S T R A C T}

The study focuses on soil and seed borne foliar blight diseases. The study area covered pothohar rain fed region of Punjab containing four districts Jhelum, Rawalpindi, Attock and Chakwal. Epidemiological surveys were conducted to check prevalence and incidence of foliar diseases. Samples were collected from 70 locations. Fungi isolated from soil samples belonged to the genera Fusarium, Aspergillus, Mucor, Penicillium, Curvularia and Rhizopus. Yield attributes were also calculated for yield production under different stresses. The results indicated that overall trend of foliar blight diseases was such that diseases took higher toll in Attock>Chakwal $>$ Jhelum $>$ Rawalpindi. Tan spot mean incidence was 7.15 in Chakwal and 2 in Attock, it was absent in Jhelum and Rawalpindi. Net blotch mean incidence was recorded highest among all diseases with values 1.47, 24.33, 13.66 and 14.55 in Chakwal, Jhelum, Rawalpindi and Attock respectively. Scald mean incidence was 2.5 in Attock only. Disease incidence of Septoria and HLB ranged from 0.8 - 2.10 in four districts. Alternariaand Fusarium were recorded highest in Jhelum and Chakwal respectively. Consequently the measured wheat yield and grains quality was affected in presence of foliar blight diseases. It needs improved agricultural practices and better management to combat diseases for higher yields.

Keywords: Foliar Blight, seed borne diseases, soil borne diseases, yield attributes, fungal diversity.

\section{INTRODUCTION}

Wheat is the major staple crop in Pakistan (Chatrath et al., 2007). It is the basic food for most of the people and it covers more farm land than any other crop (Bajwa, 1985). The people of Pakistan derives about 40-45\% nutrition from different varieties of wheat crop (Khan, 2008). In South Asia, production of wheat rose from 1595.5 million tons during period of 1960-2005. Requirement of wheat production is still increasing by 2 $2.5 \%$ annually until mid of $21^{\text {st }}$ century due to boost of population (Duveiller et al., 2007).

Among the wheat producing countries Pakistan stands at $10^{\text {th }}$ place in term of area (8.5 million hectares) and $59^{\text {th }}$ in terms of yield i.e. 21.0 million tons. Current production of wheat in Pakistan is about 95 million tons it estimated that by 2020, the demand will be about 137 million tons. Pakistan started from production of about $3,814 \mathrm{~kg}$ in 1961 and reached up to the level of 25,214

* Corresponding Author:

Email: sadiasami7@yahoo.com

(C) 2017 Pak. J. Phytopathol. All rights reserved. $\mathrm{kg}$ in 2011 (Khan et al., 2008). With collaboration of National Agricultural Research Center (NARC) \& CIMMYT although the progress has been made in wheat improvement program but still Pakistan lags behind in meeting international average of wheat yield production (Afzal et al., 2008).

About 21\% of Pakistan's GDP is derived from the agriculture sector of which wheat crop contribute significantly (Rattu et al., 2011 and Khan et al., 2008). There are many biotic and abiotic stresses that are resulting in slow wheat production in Pakistan, like level of diseases, pests and other threats. Diseases are caused by fungi, bacteria, viruses and nematodes.

About 200 diseases have been reported on the wheat crop half of which is caused by pathogens and the rest due to attack by parasites and weeds. These diseases can be transmitted from one plant to another through wind and other sources (Park, 2007). Many various physical and economic factors are present upon which wheat crop production depends. Physical factors are temp, rainfall, humidity whereas economic factors include 
cheap labor, high prices of good quality seeds, cheap transportation means, sufficient storage capacity etc. (Iqbal et al., 2010).

Wheat disease spectrum is being changed in some regions because of climate changes. Wheat growing areas may greatly be affected by climate change. The pathogens or pests that are considered as unimportant today may change to potential new risks in future (Zhang, 2005).

According to epidemiological study the high temperature, high humidity as well as long period of rainfall or dew, the combined effects of these three is conductive to foliar blight development. Foliar blight development severity also depends on other abiotic stresses like soil moisture, nutrient deficiency delayed seedling date and reducing soil fertility which will ultimately result in reducing biomass, grain yield and total kernel weight in wheat crop (Hobbs \& Gini, 1997). Globally, all the various wheat diseases are resulting in about $12.4 \%$ of yield losses annually (Oerke et al., 2004). This yield loss and low quality grains are resulting mainly through fungal pathogens rendering the grains unhygienic for human consumption. Even the total nutritive value of grains can be affected by these fungi producing mycotoxins (Galvano et al., 2001 and Hussain et al., 2010). Various fungal diseases in Pakistan Includes rusts, smuts and blights/spots etc. (Iftikhar et al., 2010). Among fungal diseases, foliar pathogens contribute significantly to reduce average yields of cereal crops. Seed-borne and soil-borne fungi of wheat crop include Alternaria spp., Aspergillus spp., Bipolaris spp., Curvulari spp., Mucor spp., Fusarium spp. and Penicillium spp. These fungi may cause different foliar blight diseases like Septoria, spot blotch, tan spot, net blotch, Alternaria and Fusarium (Hajihasani et al., 2014; Majumder et al., 2013 and Pathak \& Zaidi, 2013).

One of the aims of the study was to aware farmers at local level about these diseases and to improve their management practices. The information was extracted to move it to other agencies which are involved in agricultural policy making. The only remedy to prevent huge yield losses is to identify the cause behind the problem. Problems of wheat quality and lower productions prevail in Pothohar region of Pakistan which is third largest industry and this is a major constraint to meet the international standards. Chief aim of current study is survey of different wheat growing fields to assess different diseases and to check farmer's knowledge about it. Breeders are working hard to provide good quality germplasm but the need of the hour is to educate farmers who is neither willing to leave obsolete practices nor do they revise their management practices.

The main objectives of the study are as follows:

- To assess incidence, prevalence and severity of the foliar blight diseases in rain fed upper, middle and lower pothohar region.

- Isolation of fungal pathogens from soil and infected samples and their morphological characterization.

- To collect yield attributes and field evaluation of wheat growing fields of pothohar region.

The goal of contemporary research was to understand reasons about low crop yields, status of foliar diseases in rainfed regions and their control in environmental friendly way .More work and innovation at molecular level is still required following DNA sequencing of wheat varieties that will open gateways for biotechnology field. In this way resistant, high yielding and short duration varieties will be able to generate as requirement of current scenario. Work should be done on use of plant extracts as best possible disease remedial measure it can eradicate disease by utilizing limited natural resources.

\section{MATERIALS AND METHODS}

Survey of wheat growing fields (February, 2015): The study area contained Rawalpindi and Chakwal, Attock and Jhelum as upper, middle and lower Pothohar region respectively. Seventy (70) villages from four districts were selected as sampling sites. Questionnaires were administered in selected areas. Information about crop management practices, cropping patterns and status of foliar blight diseases was obtained from farmers to fill the questionnaires. Data about use of fertilizers, herbicides, weedicides and pesticides was also recorded.

During month of April when wheat crop at ripening and harvesting stage, second survey was conducted with purpose of calculation of disease incidence, prevalence and severity of foliar blight diseases. Disease severity was calculated with visual scale of severity, while incidence and prevalence was calculated with the help of following formulae.

$$
\text { D. } I=\frac{(\text { foliai in class } 1+\text { foliar in class } 2+\text { foliar in class } 4)}{\text { total foliar in } 4 \text { samples }} \times 100
$$




$$
\text { Foliar disease prevalence }(\%)=\frac{\text { locations showing foliar symptoms }}{\text { total locations }} \times 100
$$

Where D.I* stands for disease incidence.

\section{Collection and preparation of soil samples: Total of} 70 Soil samples were collected from wheat growing fields of sampling sites. From three corners of each wheat field 39grams of soil was taken in diagonal pattern at depth of $6-15 \mathrm{~cm}$ after that a composite sample was prepared. Crop fields were generally observed for presence or absence of foliar diseases. An overall view of the incidence and severity of foliar blight was estimated in each field.

Samples were collected in properly labeled plastic bags, and transferred to Environmental Mycology and Ecotoxicology laboratory of Department of Environmental sciences, Fatima Jinnah Women University, Rawalpindi for further analysis (Iram et al., 2005). All collected soil samples were air dried for 24 hours and grinded in pestle mortar before starting their analysis.

Fungal isolation from soil: All required apparatus were firstly sterilized in autoclave at temperature of $121^{\circ} \mathrm{C}$ for 40 minutes and dried up in oven at $95^{\circ} \mathrm{C}$. Prepared media was poured into Petri plates and allowed it to solidify for about 24 hours. Next in $10 \mathrm{~mL}$ autoclaved

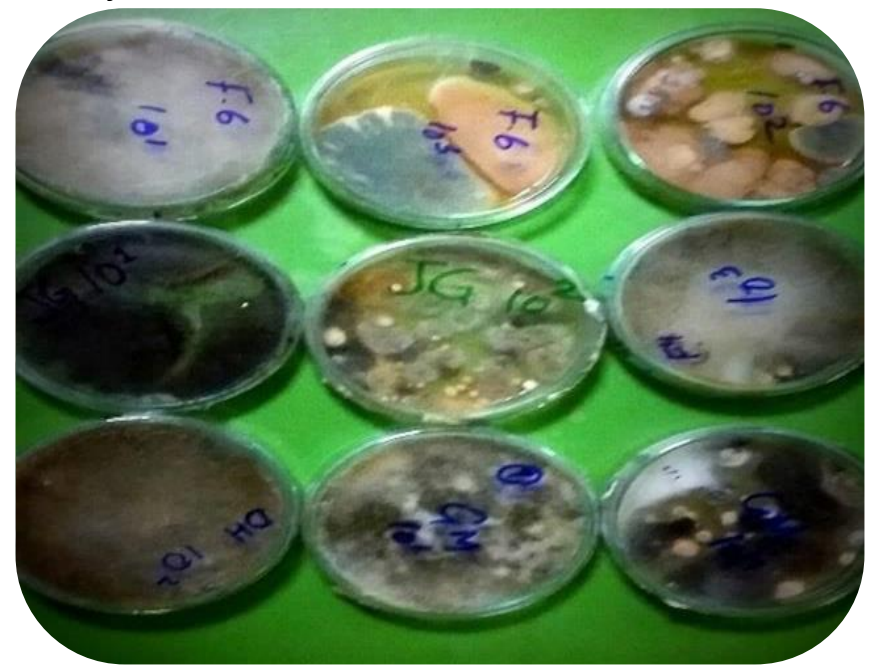

$$
\text { Colony Forming Unit (CFU) / g or CFU/ } \mathrm{ml}=\frac{a \times d}{s}
$$

distilled water one gram soil was dissolved to get an aliquot and afterwards $1 / 1000 \mathrm{~mL}$ dilutions were made. Serial dilutions from $10^{1}$ to $10^{3}$ were carried out and $1 \mathrm{~mL}$ liquid was taken for each dilution. Afterwards each of the diluted samples $(0.5 \mathrm{~mL})$ was pipette out and poured on PDA media and was incubated in incubator at $26^{\circ} \mathrm{C}$ for 7 days for morphological identification (Zafar et al., 2007).

Morphological Identification of Fungal Colonies: Different fungal colonies were grown on petriplates after 7 days. These colonies were morphologically identified by using compound microscope at various magnifications like 100X, 400X and 1000X. All fungi were characterized on basis of hyphae color, conidia shape or structure, septation and any other visible morphological structure. The identified data was noted (Zafar et al., 2006).

Measurement of Colony Forming Unit (CFU): From each petri plate number of fungal colonies was counted by using colony forming unit formula as it is given below:

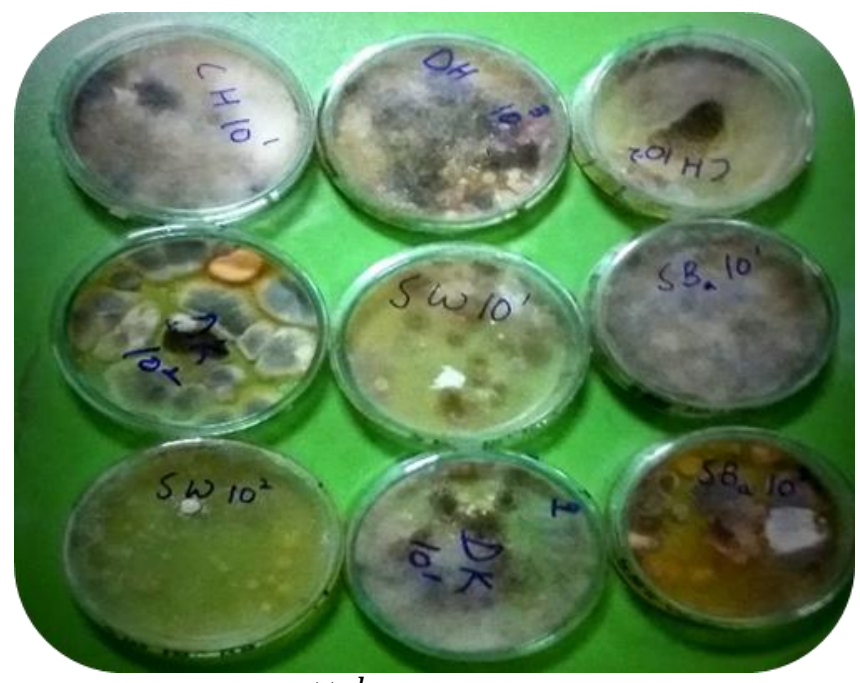

where, $\mathrm{a}=$ average number of colonies on the petriplates, $\mathrm{d}=$ dilution factor $(10,000)$ and $\mathrm{s}=$ dry weight of the sample or volume of water in ml. (Sharma et al., 2014)

Collection of yield attributes: Yield attributes of respective study sites were also analyzed following diagonal pattern by measuring productive number of tillers in per meter length and area.in total approximately $90-100$ plants were analyzed by counting grains number per spike. From all the selected locations of four districts, grains were collected out of which about one thousand grains were weighed to check the overall wheat production (Anneke \& Benson, 2011).

\section{RESULTS AND DISCUSSIONS}

Epidemiological assessment of foliar blight disease

in study area: Survey of upper, middle and lower Pothohar region depicted clear status of foliar blight 
disease incidences of corresponding fields. In the case of Rawalpindi district the disease remarkably observed was Fusarium leaf blotch while scald epidemic was completely absent.

In case of Upper pothohar region the peak incidence of Fusarium leaf blotch, net blotch and Alternaria leaf blight reported in this area with mean incidence values of $9.91 \%, 7.56 \%$ and $4.78 \%$ respectively. Lowest values of tan spot, HLB and Septoria leaf blotch was reported in this region with mean percentages of $3.56 \%, 1.73 \%$ and $1.25 \%$ respectively, while scald was totally absent (Figure 1). The wheat production was mainly affected by Fusarium in this region congruently health of crops was at stake. (Webley et al., 1997)

The case of district Jhelum was quite different with high incidence of two foliar blight diseases i.e. net blotch and Alternaria leaf blotch having values of $24 \%$ and $13 \%$ respectively (Figure 2). However, least incidence of Fusarium was recorded only in this region. Though all the other foliar diseases were negligible here as most of the crops of fields were not at all susceptible to disease epidemics (Konig et al., 2013)

Scald disease was present only at district Attock with disease incidence of $2.5 \%$ (Figure 3 ). While minimum value of Helminthosporium leaf blotch was recorded with mean incidence percentage of $0.25 \%$. This area was found to be affected by diverse number of epidemics as none of the foliar blight disease was absent here.

The possible reasons for such remarked fluctuation in results might be attributed to number of reasons as disease proliferation depends on host susceptibility, various weather conditions (temperature, humidity, rainfall pattern, wind speed and direction) presence of inoculum, seed sown (quality, quantity and treatment), awareness level among farmers, sowing date of crop, growth stages of wheat crop, presence of weeds and vice versa. Such types of responsible factors are also proved by many scientists (Duveiller et al., 2007).

Many of the Chakwal sites were affected by either one type of foliar blight disease or another. Several reasons behind Helminthosporium leaf blotch and Fusarium leaf blotch proliferation in this area are prevalence of warm humid climate and no till practices that is conducive for disease development. In few areas tan spot was reported this might have been caused by residues remains of previous crops in those fields.

In Jhelum although temperature and humidity levels were supportive for disease production, however farmers of the area might be equipped with proper awareness regarding combating against disease severity. They used resistant varieties of wheat crop along with other measures like treatment of seeds. Above all they seeded crop in mid dates of October that is ideal time period for obtaining high yield of wheat. In some areas disease attack could have happened because of previous source debris that acting as primary inoculum.

Case of Attock was totally different and this area could be designated as hot spot of foliar blight diseases due to ideal conditions which prevailed here for disease development and dispersal as well. Neither residues of previously grown crops were not removed nor were any fungicidal treatment applied by the farmers. Pathogens attacked earlier on crop which lead very prominent symptoms at booting stage on flag leaves, seeds, kernels or we can say whole plant was badly affected that resulted in reduced yield. These all conditions lead to sever out broke of disease (Batool et al., 2014).

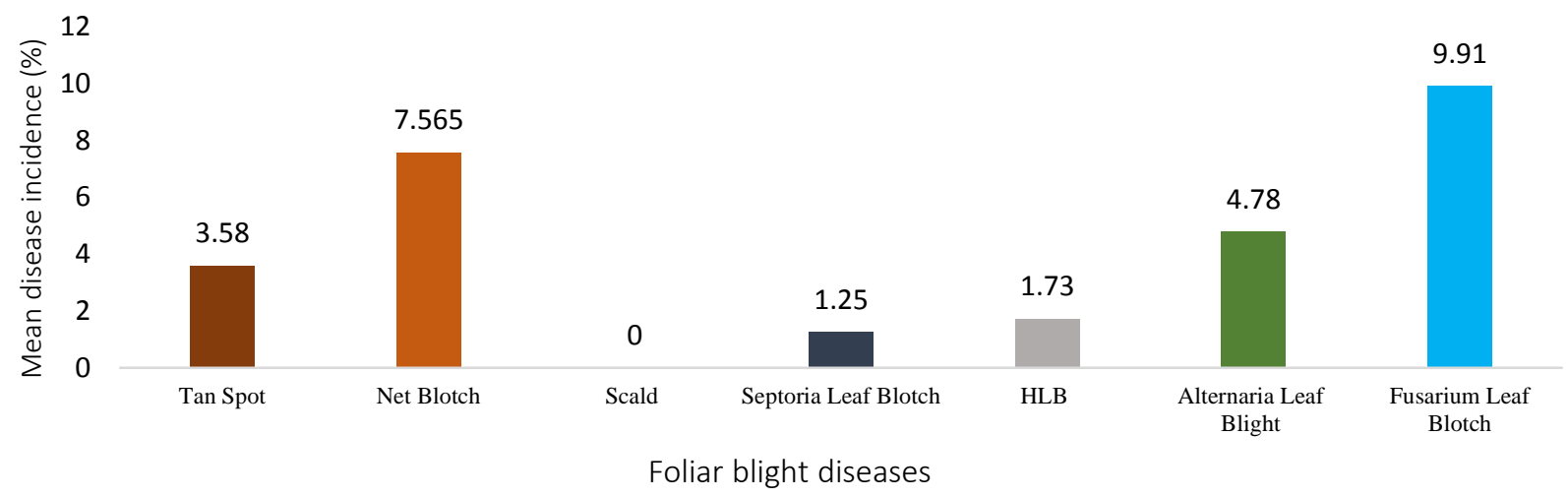

Figure 1. Foliar blight diseases in District Rawalpindi and Chakwal; Upper Pothohar Region. 


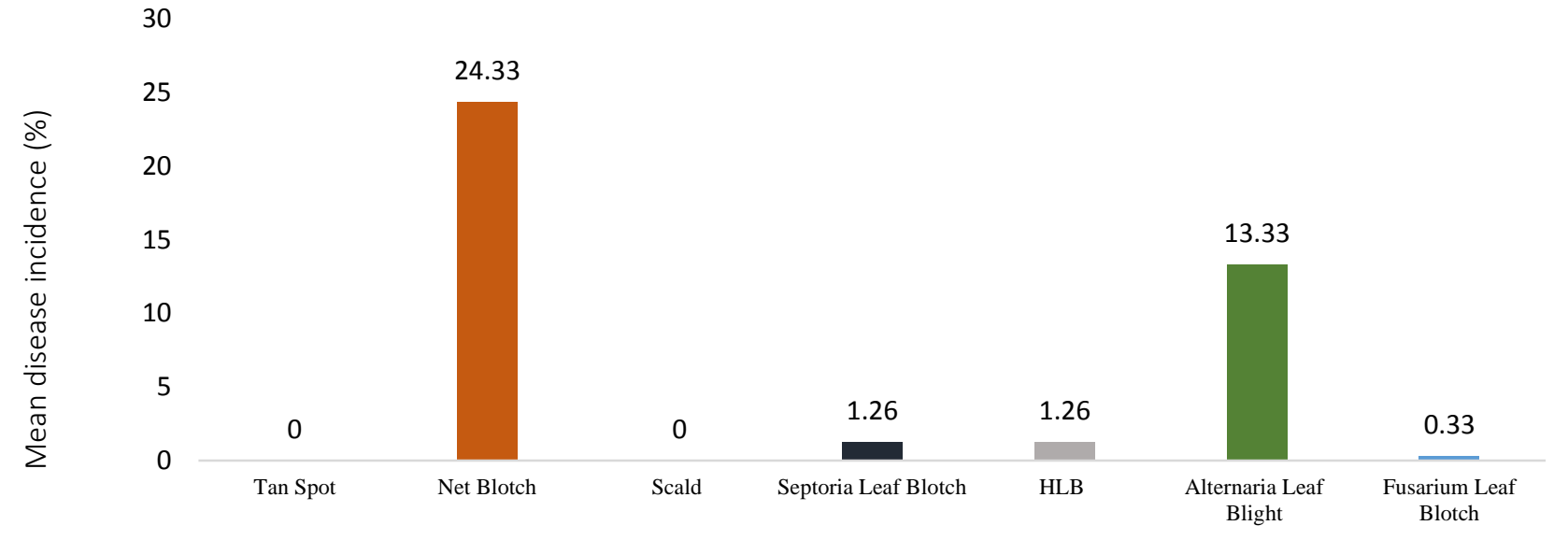

Foliar blight diseases

Figure 2. Foliar blight diseases in District Jhelum ; Lower Pothohar Region.

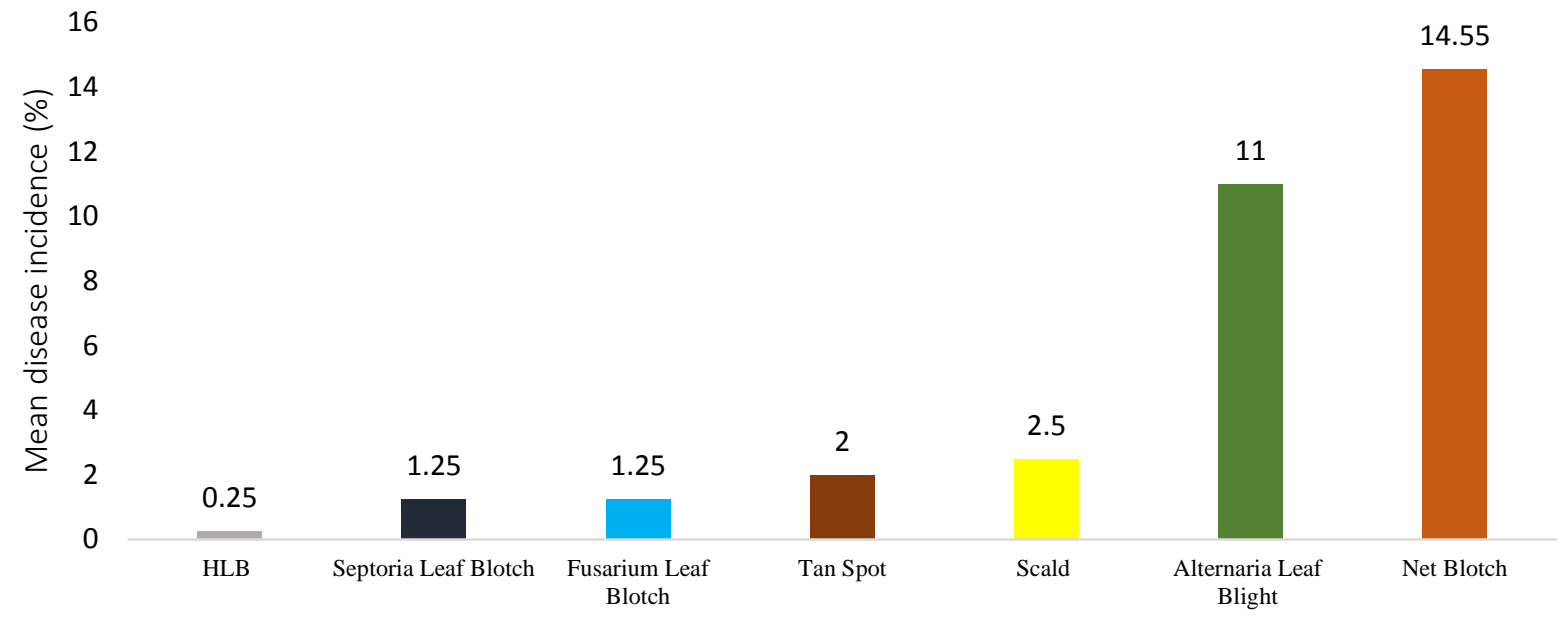

Foliar blight diseases

Figure 3. Foliar Blight diseases in District Attock; Middle Pothohar Region

3.2 Isolation of pathogen and characterization on the basis of morphology: Present research designates a great diversity among fungal species of selected soil samples. The identified fungal colonies primarily belonged to various genera like Mucor, Fumigatus, Fusarium, Acremonium, Penicillium, Curvularia spp., Rhizopus, Aspergillus, and A. flavus. Soil sample richness can be checked by observing total number of colonies grown on Petri plates. According to the research findings of Majumder, identification of pathogen is key stone for management of wheat crop and he also isolated similar types of fungus as found in present research. Likewise Batool along with her coworker's isolated various type of fungus from soil to know its fungal diversity (Majumder et al., 2013; Batool et al., 2014). 
Pak. J. Phytopathol., Vol. 29 (01) 2017. 157-166

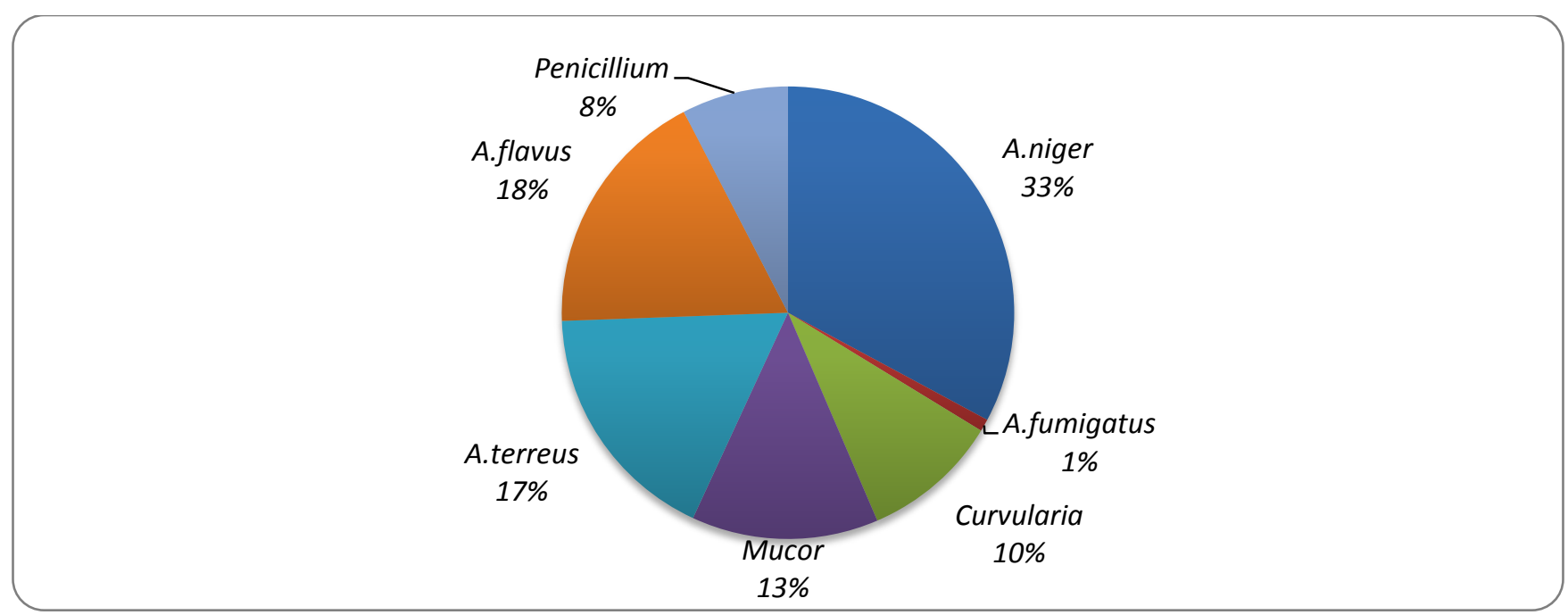

Figure 4. Fungal diversity from soil of District Chakwal

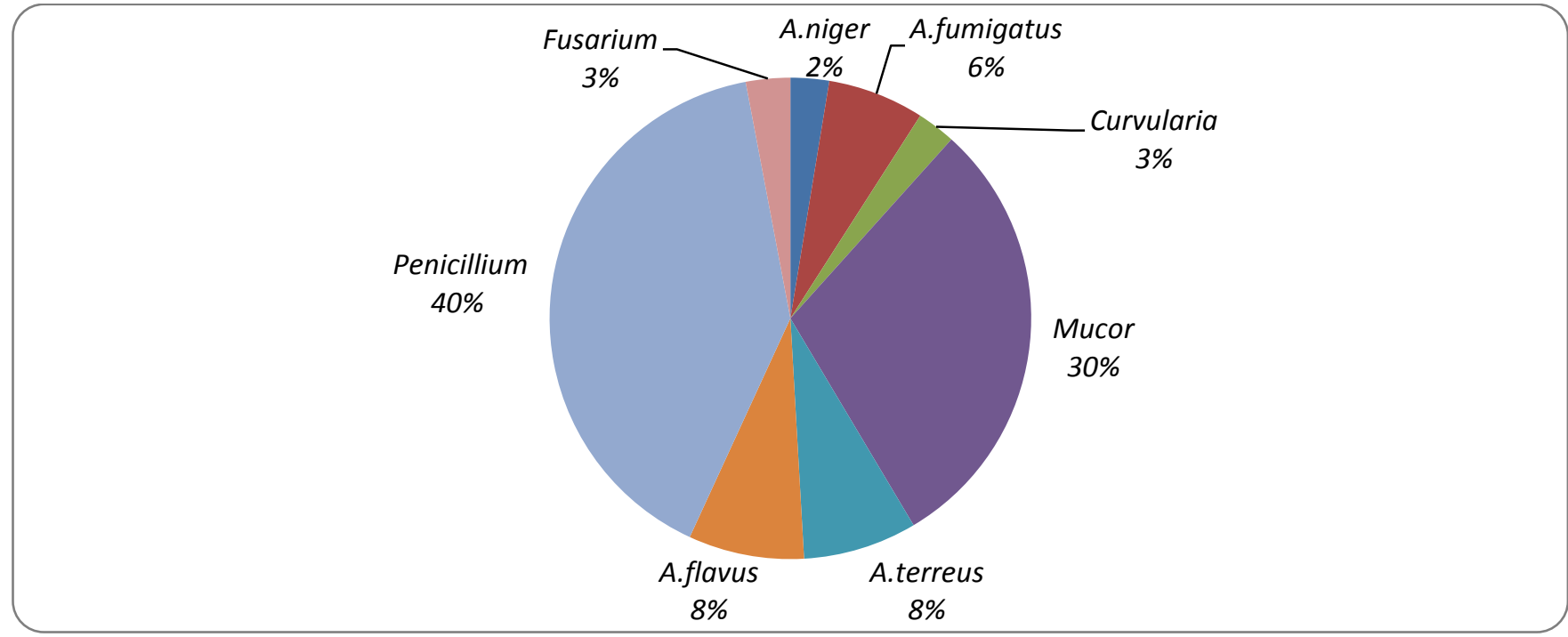

Figure 5. Fungal diversity from soil of District Rawalpindi

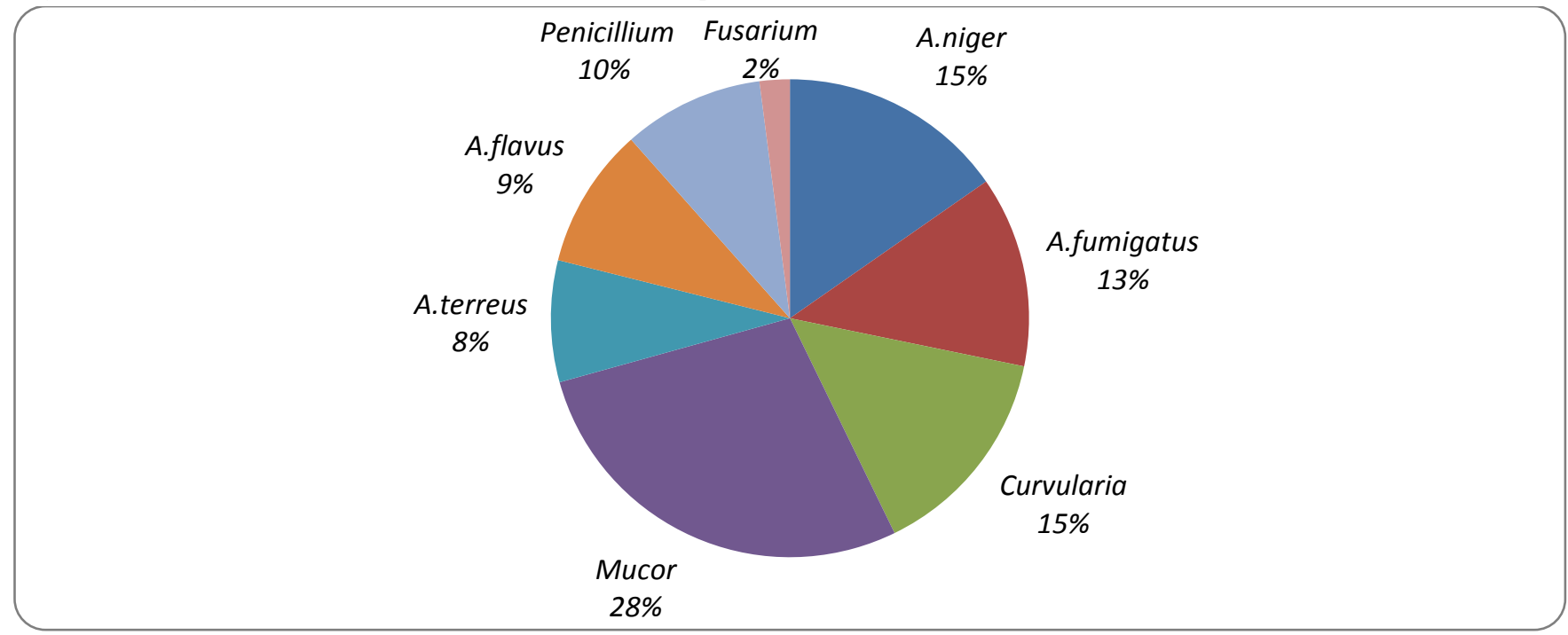

Figure 6. Fungal diversity from soil of District Jhelum 


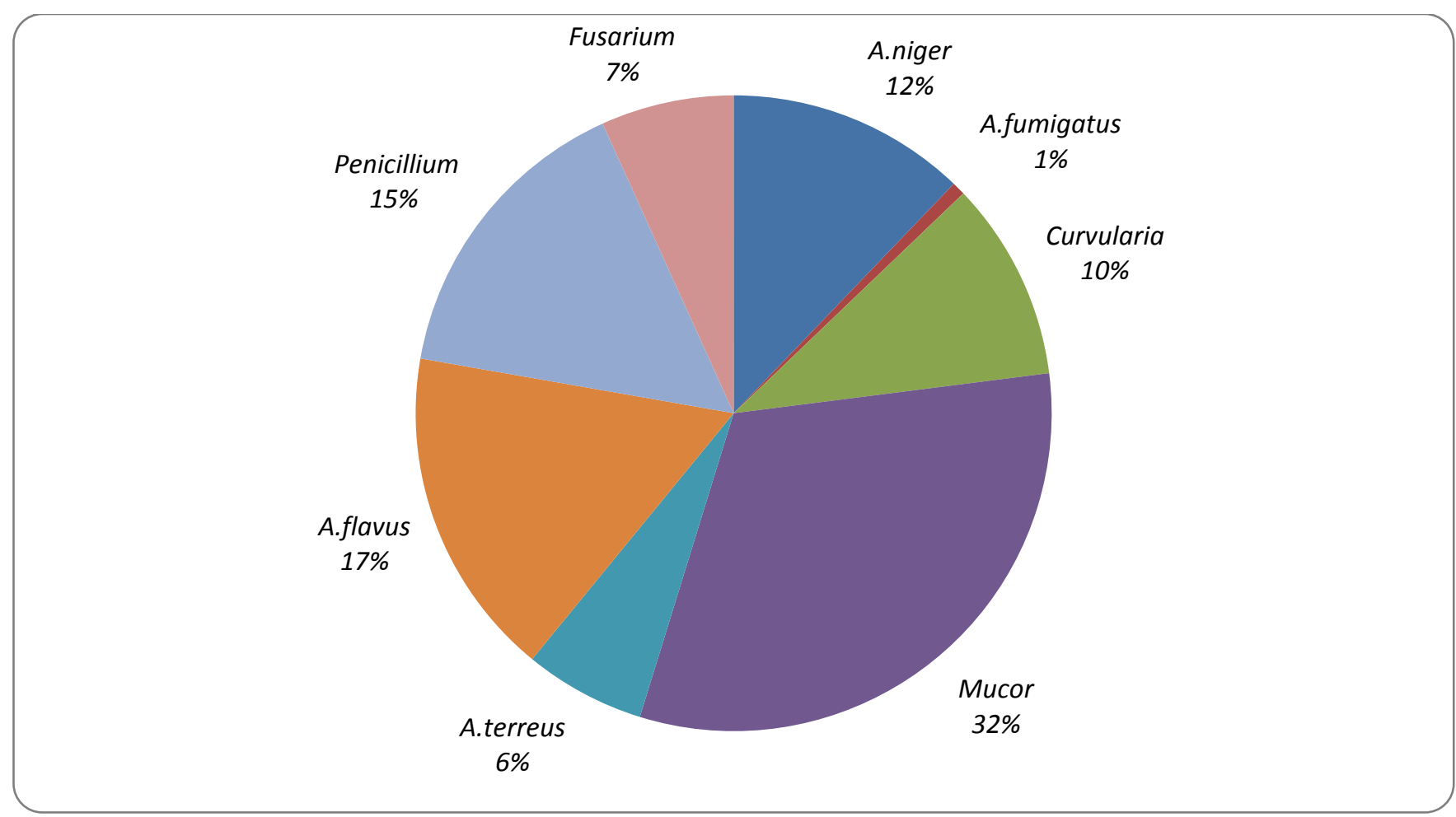

Figure 7. Fungal diversity from soil of District Attock

Field evaluation of wheat growing fields of Pothohar region: Wheat crop yield were noted for all the 70 observed fields of upper, lower and middle Pothohar region. A diverse range of data obtained from this survey. Yield was measured to have an idea about health status of wheat crop in each area. Annual yield of each location is listed in Table 3.8.

According to the survey results of upper Pothohar region, highest yield of $840 \mathrm{~kg}$ per acre is recorded at fields of Khanpur in Rawalpindi whereas lowest of 560 $\mathrm{kg}$ per acre is observed in almost 3 fields of this region. In Lower Pothohar region very much satisfactory yield was depicted in almost all the fields that is attributed to farmer's awareness regarding the health of their fields. Highest value of $920 \mathrm{~kg}$ per acre was recorded at Kalowal fields while minimum value was recorded at Sukha with yield production of almost $760 \mathrm{~kg}$ per acre.

Foliar blight epidemics badly attacked the wheat cultivars at Attock district because farmers were mainly unconcerned about their fields. Severe attacks to crop were leading togreat reduction of yield out puts in all the fields with exception at Dhok Momin with annual production of wheat crop as $720 \mathrm{~kg}$ per acre.The overall highest wheat production was recorded at district Jhelum followed by district Rawalpindi and Chakwal with average value of wheat yield as $845.2 \mathrm{~kg}$ per acre,
$795.6 \mathrm{~kg}$ per acre and $754.4 \mathrm{~kg}$ per acre respectively. While minimal yield of $576 \mathrm{~kg}$ per acre was observed at Attock district.Resistance to diseases and consequently high yield is due to better levels of awareness among farmers who might be alert to the disease epidemics well before time. They adopted prerequisite steps to avoid foliar blight disease propagation by either using treated seeds or by removing residues of previous crops through proper tillage.

According to the findings, still obsolete techniques are practiced for crop production and management, as farmers are not ready to leave their old practices of farming because of many economic factors; they use traditional seeds without any fungicidal treatment. Most of the farmers rely on natural rainfall they are not able to artificially irrigate their fields, all these factors synergies to give less production (Laghari et al., 2010). Photosynthetic activity of plant is reduced because of various lesions on leaves, hence forth most of the area was covered by disease as a result, seeds produced are deprived of nutrients or we can say over all yield is affected. Photosynthetic activities can be enhanced through proper irrigation that would increase leave area, rate of crop growth and above all increased biomass will result (Ram et al., 2013). 
Pak. J. Phytopathol., Vol. 29 (01) 2017. 157-166

Table 1.Wheat crop yield of upper, lower and middle Pothohar region

\begin{tabular}{|c|c|c|c|c|c|c|c|c|}
\hline \multicolumn{5}{|c|}{ Upper Pothohar } & \multirow{2}{*}{\multicolumn{2}{|c|}{$\begin{array}{c}\text { Lower Pothohar } \\
\text { Jhelum }\end{array}$}} & \multirow{2}{*}{\multicolumn{2}{|c|}{$\begin{array}{c}\text { Middle Pothohar } \\
\text { Attock }\end{array}$}} \\
\hline & Rawalpindi & & Chakwal & & & & & \\
\hline 1 & KallarSyedan & 18 & Khanpur & 21 & Bora Jungle & 22 & DhokMalal & 12 \\
\hline 3 & SalriMor & 20 & Sehgalabad (b) & 16 & Baala & 20 & DhokItabar & 12 \\
\hline 4 & DhokMukadam & 20 & Chattal & 21 & Bhatiyan & 22 & Jaffar & 14 \\
\hline 5 & Mishran Mora & 21 & Dab & 16 & Sukha & 19 & Gulial & 15 \\
\hline 8 & Gujar Khan & 16 & Janga & 14 & Chontra & 22 & Khunda & 17 \\
\hline 9 & Sanghori & 18 & DhokTaliyan & 20 & GujranMalot & 20 & DhokKirchiyal & 14 \\
\hline 10 & Kulian Sharif & 17 & Dhokhijri & 15 & Mong & 21 & Basal & 12 \\
\hline 11 & Duma & 20 & Jhatla & 14 & Khanewal & 23 & Thatta & 13 \\
\hline 12 & DhokNamkeen & 23 & Ijazabad & 18 & Dina & 24 & Mthial & 16 \\
\hline 17 & & & Khewal & 15 & & & Sakki & 17 \\
\hline 18 & & & Kajli & 15 & & & DhokMomin & 18 \\
\hline 19 & & & MulhalMughlan & & & & Gaggan & 15 \\
\hline 20 & & & & & & & Bangesh Abad & 14 \\
\hline Mean & & 18.8 & & 16.9 & & 21.1 & & 14.5 \\
\hline
\end{tabular}

\section{STATISTICAL ANALYSIS}

Results of the data were statistically analyzed by applying ANOVA. Variances analyzed relation between area and diseases plus diseases and their incidences. Least square difference (LSD) all pairwise comparisons test of incidence for disease is given in figure 3.8. Results are quite significant as disease 5(net blotch) had highest incidence that's why lettered as A, this indicated net blotch incidence was greatly different from other foliar diseases followed by disease 7 (Alternaria leaf blight), 4 (Fusarium leaf blotch) and 1(tan spot) while disease 6 (Septoria leaf blotch), 2 (HLB) and 3 (scald) were least different from one another designated with letter $\mathrm{C}$ (Figure 8). 


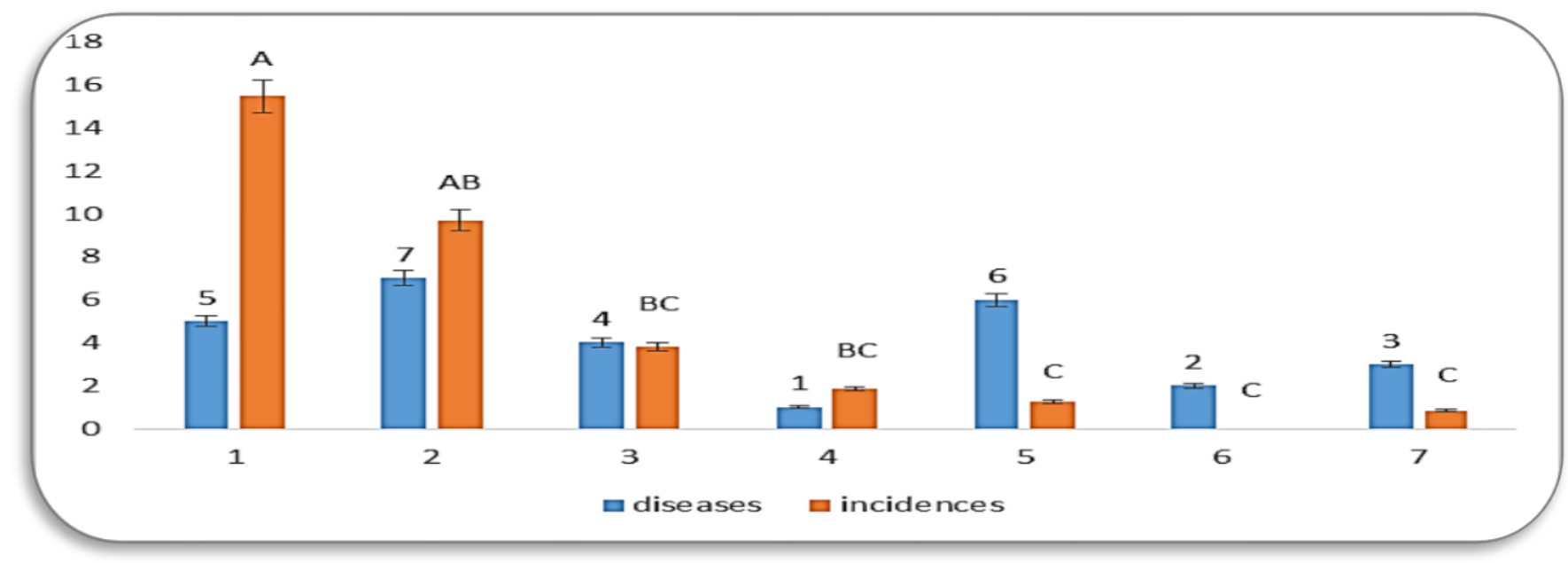

Figure 8. Comparisons test of incidence for diseases

\section{CONCLUSIONS}

The current research work is inclined to foliar blight wheat diseases at upper, middle and lower Pothohar region. Grain filling period and booting stage of wheat crop was checked through questionnaire based surveys, regarding disease status and crop management practices adopted by growers. According to the study disease development and propagation was noted in almost all of the fields with exception of few fields and strong link exists between sowing date, resistant cultivars use, and circadian fluctuation of weather, previous crops debris and high yield of good quality wheat crop. Weed is one of major factor that is actually reducing nutritional value and production of wheat crop.

In many locations except at Jhelum, farmers were not much concerned regarding heavy loss of wheat grains resulted from either adopting inappropriate disease management practices or because of obsolete agronomics techniques due to unaffordability. Many growers were totally depending on natural irrigation rather than provision of water through artificial means. Short time compelled growers to sow seeds without being treated and economic burden further resulted in not using fungicide at any of the growth stages from early seedling to late maturing period. To have high yield in short duration of time, farmers go for susceptible varieties that are through heavy producers of wheat crop but they are actually susceptible to great number of diseases.

\section{REFERENCES}

Afzal, S. N., M. I. Haque, M. S. Ahmedani, A. Rauf, M. Munir, S. S. Firdous and I. Ahmad. 2008. Impact of stripe rust on kernel weight of wheat varieties sown in rainfed areas of Pakistan. Pak. J. of Bot. 40(2): 923929.

Fermont, A. \& T. Benson. 2011. Estimating yield of food crops grown by smallholder farmers. International Food Policy Research Institute, Washington DC, 168.

Villareal, R. L. and A. R. Klatt. 1985. Wheat for more tropical environments. A proceedings of the international symposium. In Centro Internacional de Mejoramiento de Maiz y Trigo, Mexico, DF (Mexico). Symposium on Wheat for More Tropical Environments. Mexico, DF (Mexico). 24-28 Sep 1984.

Batool, S. Q., S. Iftikhar and S. S. Ahmad. 2014. Epidemiological Estimation of Foliar Rust Diseases of Wheat and Pathological Assessment of Different Rust Pathogens Isolated from Rainfed Areas of Punjab, Pakistan. Inter. J. of Scien. \& Engin. Re. 363377.

Chatrath, R., B. Mishra, G. O. Ferrara, S. K. Singh, and A. K. Joshi. 2007. Challenges to wheat production in South Asia. Euphy. 157(3): 447-456.

Duveiller, E., R. P. Singh and J. M. Nicol. 2007. The challenges of maintaining wheat productivity: pests, diseases, and potential epidemics. Euphy. 157(3): 417-430.

Galvano, F., A. Piva, A. Ritieni and G. Galvano. 2001. Dietary strategies to counteract the effects of mycotoxins: a review. J. of food Protect. 64(1): 120131.

Hajihasani, M., A. Hajihassani and S. Khaghani. 2012. Incidence and distribution of seed-borne fungi associated with wheat in Markazi Province, Iran. Afri. J. of Biotec. 11(23): 6290-6295. 
Hobbs, P. R., and G. S. Giri. 1997.Reduced and zerotillage options for establishment of wheat after rice in South Asia (pp. 455-465). Springer Netherlands.

Hussain, S. and M. A. Maqsood. 2010. Increasing grain zinc and yield of wheat for the developing world: A Review. E. J. of Food and Agri. 22(5): 326.

Iftikhar, S., S. Asad, and M. Anjum. 2010. Incidence of Bipolaris sorokiniana in Punjab and Khyber pakhtoonkhawa, Pakistan. Pak. J. of Phytopathol. 22(2): 95-97.

Iqbal, M. J., I. Ahmad, K. A. Khanzada, N. Ahmad, A. R. U. Rattu, M. Fayyaz, A. M. Kazi. 2010. Local stem rust virulence in Pakistan and future breeding strategy. Pak. J. of Bot. 42(3): 1999-2009.

Khan, F. S., S. Razzaq, K. Irfan, F. Maqbool, A. Farid, I. Illahi and T. U. Amin. 2008. Dr. Wheat: a Webbased expert system for diagnosis of diseases and pests in Pakistani wheat. In Proceedings of the World Congress on Engineering (1): 2-4.

König, J., D. Perovic, D. Kopahnke, and F. Ordon. 2013. Development of an efficient method for assessing resistance to the net type of net blotch (Pyrenophorateres $\mathrm{f}$. teres) in winter barley and mapping of quantitative trait loci for resistance. Mol. Breed. 32(3): 641-650.

Laghari, G. M., F. C. Oad, S. Tunio, A. W. Gandahi, M. H. Siddiqui, A. W. Jagirani and S. M. Oad. 2010. Growth, yield and nutrient uptake of various wheat cultivars under different fertilizer regimes. Sarhad J. of Agri. 26(4): 489-497.

Majumder, D., T. Rajesh, E. G. Suting and A. Debbarma. 2013. Detection of seed borne pathogens in wheat: recent trends. Aust. J. of Crop Sci. 7(4 special issues): 500 .
Oerke, E. C., and H. W. Dehne. 2004. Safeguarding production losses in major crops and the role of crop protection. Crop Protec. 23(4): 275-285.

Pathak, N., \& Zaidi, R. K. 2013. Studies on seed-borne fungi of wheat in seed health testing programme. Arch. of Phytopathol. and Plant Protec. 46(4): 389-401.

Park, R. F., H. S. Bariana and C. S. Wellings and C. S. Welling. 2007. Preface. Aus. J. of Agri. Res. 58- 469.

Ram, H., V. Dadhwal, K. K. Vashist, H. Kaur. 2013. Grain yield and water use efficiency of wheat (Triticum aestivum L.) in relation to irrigation levels and rice straw mulching in North West India. Agri. Water Manag. 128: 92-101.

Rattu, R. A., S. Asad, M. Fayyaz, M. Zakria, S. Iftikhar and Y. Ahmed. 2011. Status of foliar diseases of wheat in Punjab, Pakistan. J. of Mycopathol. 9(1): 39-42.

Sharma, R. and G. Sumbali. 2014. Fungal diversity associated with the commercial grades of walnut kernels sold in the markets of Jammu and Kashmir State (India). Intern. J. of Pharm. Sci. Inven. 3: 50-57.

Webley, D. J., K. L. Jackson, J. D. Mullins, A. D. Hocking and J. I. Pitt. 1997. Alternaria toxins in weatherdamaged wheat and sorghum in the 1995-1996 Australian harvest. Crop and Pasture Sci. 48(8): 1249-1256.

Zhang, X. 2005. Modélisation de la réponse des variétés de blé au niveaud'intensification.Influence de la pression de maladies foliaires. These de Doctorat, Institut National Agronomique ParisGrignon, France.

Zafar, S., F. Aqil and I. Ahmad. 2007. Metal tolerance and biosorption potential of filamentous fungi isolated from metal contaminated agricultural soil. Bio Tech. 98(13): 2557-2561. 